\title{
Effects of dietary lysine levels on jejunal expression of amino acids transporters and hindgut microflora in weaned pigs
}

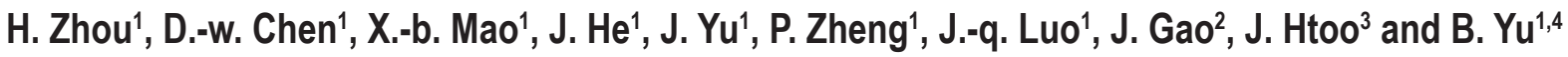 \\ ${ }^{1}$ Sichuan Agricultural University, Institute of Animal Nutrition, Chengdu, 611130, China \\ ${ }^{2}$ Evonik Degussa (China) Co., Ltd. Health \& Nutrition, Beijing, 100026, China \\ ${ }^{3}$ Evonik Industries AG Health \& Nutrition, Hanau-Wolfgang, 63457, Germany
}

KEY WORDS: amino acids transporters, microbial flora, lysine, piglets

Received: $\quad 12$ April 2017

Revised: 18 March 2018

Accepted: 1 August 2018

${ }^{4}$ Corresponding author:

e-mail: ybingtian@163.com

\begin{abstract}
The objective of the study was to evaluate the effects of increasing dietary standardized ileal digestible (SID) lysine (Lys) level on the expression of jejunal amino acids (AAs) transporters and the microflora in the hindgut of weaned pigs. One hundred and twenty weanling pigs weighing $8.10 \pm 0.48 \mathrm{~kg}$ were randomly assigned according to body weight and sex to 5 treatments with 6 replicates per treatment and 4 pigs per replicate. Pigs were fed diets with $0.98,1.11,1.23,1.35$ or $1.48 \%$ of SID Lys for 28 days. The mRNA expression of cationic amino acids transporter 1 (CAT1) in jejunum was higher in groups fed with $1.23,1.35$ and $1.48 \%$ SID Lys addition $(P<0.05)$. There was stated a linear increase in the mRNA expressions of CAT1, excitatory amino acids carrier 1 (EAAC1) and peptide transporter T1 (PEPT1) (linear, $P<0.05)$. In the caecum, the populations of bacteria and the content of butyric acid were significantly influenced $(P<0.05)$ by dietary SID Lys. In animals fed diet with $1.35 \%$ SID Lys a content of butyric acid was the highest $(P<0.05)$. Moreover, the populations of Lactobacillus and Bifidobacterium in caecum and colon increased (linear, $P<0.05$; quadratic, $P<0.05)$ as dietary SID Lys level increased. The obtained results showed that dietary SID Lys level may influence AAs absorption and promote the hindgut health. The suggested supplementation of SID Lys to the weaned pigs' diet is $1.35 \%$.
\end{abstract}

\section{Introduction}

Amino acids (AAs), important substrates for the synthesis of proteins and other nitrogenous compounds, are also key regulators of major metabolic pathways essential for organism maintenance, growth, immunity and reproduction (Jobgen et al., 2006; Suenaga et al., 2008). It is well known that the intestinal nutrients absorption is mediated by transporter proteins expressed on enterocytes. AAs are transported into the cell by several specific transporters (Verrey et al., 2004) or as di- and tri- peptides by the peptide transporter (Leibach and Ganapathy, 1996). For example, transporters have been characterized as specific for basic amino acids (e.g., cationic amino acids transporter 1, CAT1), neutral amino acids (e.g., system B0 neutral amino acids transporter, B0AT1) and acidic amino acids (e.g., excitatory amino acids carrier 1, EAAC1) (Kanai and Hediger, 2003). The AAs transporters: B0AT1, CAT1, EAAC1 and peptide transporter T1 (PEPT1) are closely associated with AAs absorption capacity in the small intestinal epithelium (Regnault et al., 2002; Hu et al., 2008). In swine diets, Lys is 
typically the first limiting AA (Gatrell et al., 2013). A deficiency or excess of Lys can reduce or increase nitrogen retention and whole-body protein turnover (Ren et al., 2007), and affect growth performance, carcass characteristics (Apple et al., 2004), serum parameters (Cameron et al., 2003) and nutrient digestibility (Kim et al., 2011). It has been reported that changes in nutrient content can affect the levels of AAs transporters in the small intestine, skeletal muscle and mammary tissue (Laspiur et al. 2009). However, only few studies on the regulation of AAs transporters mRNA expression by dietary standardized ileal digestible (SID) Lys levels in porcine jejunum have been reported.

The intestinal microflora built of huge amounts of a vast variety of microorganisms plays a key role in keeping individual health. It has been described as an integral part of the host, constituting a socalled 'metaorganism' (Qin et al., 2010). The importance of intestinal microflora to health has gained extensive researchers attention in the last years. It is proven that dietary composition is one of the major factors that can influence the microbial population in the gastrointestinal tract (Zhang et al., 2010). However, it is still unknown whether dietary SID Lys can modulate the microbial population in hindgut of weaned pigs.

Identifying different SID Lys levels that can regulate AAs transporters and the hindgut microflora in weaned pigs is of enormous nutritional importance. Therefore, the aim of the present study was to determine the effects of different dietary SID Lys levels on the expression of AAs transporters in jejunum and changes in microbial population and metabolites in caecum and colon of weaned pigs.

\section{Material and methods}

The experimental design and procedures were approved by the Animal Care and Use Committee of Sichuan Agricultural University (Ya'an, China). The experiment was conducted at the swine research facility of the Institute of Animal Nutrition, Sichuan Agricultural University (Ya'an, China).

\section{Animals, housing and dietary treatments}

In total 120 crossbred [Duroc $\times$ (Landrace $\times$ Yorkshire)] pigs weaned at $21 \pm 1$ day of age were obtained from a commercial farm (New Hope Group, Sichuan, China). The experiment lasted 33 days ( 5 days of adaptation and 28 days of feeding experimental diets). Pigs with initial body weight $(\mathrm{BW})$ of $8.10 \pm 0.48 \mathrm{~kg}$ were assigned to
1 of 5 dietary treatments depending on the BW and sex. Each treatment had 6 replicate pens with 4 pigs per pen. Each pen $(2.5 \times 1.8 \mathrm{~m})$ was equipped with a 4-hole self-feeder and a single nipple-waterer, allowing pigs to have ad libitum access to feed and water. Room temperature for the first week was initially set at $28^{\circ} \mathrm{C}$ and was gradually decreased to $25^{\circ} \mathrm{C}$ by the end of the trial.

The experimental diets were based on maize, soybean meal and crystalline AAs. The compositions of these diets are given in Tables 1 and 2, respectively. The 5 diets were formulated to contain 0.98 , $1.11,1.23,1.35$ and $1.48 \%$ SID Lys. L-Lys $\cdot \mathrm{HCl}$ was supplemented to achieve the target SID Lys contents. Crystalline AAs (L-Threonine, DL-Methionine, L-Tryptophan, L-Isoleucine, L-Valine, L-Leucine, L-Histidine, and L-Phenylala-nine; Shanghai Immense Chemical Co., Ltd., Shanghai, China) were also supplemented to maintain the established ideal ratios (AMINO Pig ${ }^{\circledR}$ 1.0, Evonik Industries, HanauWolfgang, Germany). Diets were formulated based on values of AAs content and SID values in ingredients. All diets were formulated to contain similar net energy (NE) content ( $2510 \mathrm{kcal} / \mathrm{kg}$ ), and the NE values of ingredients were based on the recommendations of the National Research Council (NRC, 2012).

Table 1. Compositions of the experimental diets, as-fed basis

\begin{tabular}{lccccc}
\hline \multirow{2}{*}{ Ingredients, \% } & \multicolumn{5}{l}{ SID Lys ${ }^{1}, \%$} \\
\cline { 2 - 6 } & 0.98 & 1.11 & 1.23 & 1.35 & 1.48 \\
\hline Maize & 62.69 & 63.25 & 64.04 & 65.15 & 66.68 \\
Soybean meal & 22.56 & 21.82 & 20.79 & 19.39 & 17.46 \\
Whey powder & 6.00 & 6.00 & 6.00 & 6.00 & 6.00 \\
Spray-dried plasma & 3.00 & 3.00 & 3.00 & 3.00 & 3.00 \\
Soybean oil & 2.41 & 2.22 & 1.91 & 1.47 & 0.84 \\
Limestone & 0.73 & 0.73 & 0.75 & 0.73 & 0.72 \\
Di-calcium phosphate & 1.28 & 1.28 & 1.28 & 1.32 & 1.36 \\
L-Lysine · HCL & 0.15 & 0.33 & 0.52 & 0.72 & 0.94 \\
DL-Methionine & 0.09 & 0.17 & 0.26 & 0.34 & 0.43 \\
L-Threonine & 0.03 & 0.12 & 0.20 & 0.30 & 0.41 \\
L-Tryptophan & 0.03 & 0.06 & 0.09 & 0.13 & 0.16 \\
L-Valine & - & - & 0.09 & 0.20 & 0.31 \\
L-Isoleucine & - & - & 0.03 & 0.13 & 0.22 \\
L-Phenylalanine & - & - & - & 0.06 & 0.16 \\
L-Histidine & - & - & - & 0.03 & 0.09 \\
L-Leucine & - & - & - & 0.01 & 0.19 \\
Mineral-vitamin premix ${ }^{2}$ & 0.50 & 0.50 & 0.50 & 0.50 & 0.50 \\
Salt & 0.38 & 0.38 & 0.38 & 0.38 & 0.38 \\
Choline chloride & 0.15 & 0.15 & 0.15 & 0.15 & 0.15 \\
\hline
\end{tabular}

${ }^{1}$ diets supplemented with standardized ileal digestible lysine at a dose of $0.98,1.11,1.23,1.35$ or $1.48 \% ;{ }^{2}$ supplemented per $\mathrm{kg}$ of diet: IU: vit. A 8000 , vit. D 32000 , vit. E 20; mg: vit. $B_{1} 1.5$, vit. $B_{2} 5.6$, vit. $B_{12} 0.02$, vit. $B_{6} 1.5$, vit. $K 32$, calcium pantotenate 10 , nicotinic acid 15 , biotin 0.1 , folic acid 0.6 , $\mathrm{Fe}\left(\mathrm{FeSO}_{4}\right) 100, \mathrm{Cu}\left(\mathrm{CuSO}_{4} \cdot 5 \mathrm{H}_{2} \mathrm{O}\right) 20$, $\mathrm{Zn}\left(\mathrm{ZnSO}_{4}\right)$ 100, $\mathrm{Mn}\left(\mathrm{MnSO}_{4}\right) 60, \mathrm{I}(\mathrm{KI}) 0.3$, Se $\left(\mathrm{Na}_{2} \mathrm{SeO}_{3}\right) 0.3$ 
Table 2. Calculated nutritional content of the experimental diets, as-fed basis ${ }^{1}$

\begin{tabular}{|c|c|c|c|c|c|}
\hline \multirow{2}{*}{ Indices } & \multicolumn{5}{|l|}{ SID Lys $2, \%$} \\
\hline & 0.98 & 1.11 & 1.23 & 1.35 & 1.48 \\
\hline $\mathrm{CP}, \%$ & $18.50(18.50)$ & $18.50(18.24)$ & $18.50(18.02)$ & $18.50(18.34)$ & $18.50(18.37)$ \\
\hline $\mathrm{NE}, \mathrm{kcal} / \mathrm{kg}$ & 2510 & 2510 & 2510 & 2510 & 2510 \\
\hline \multicolumn{6}{|l|}{ SID AAs, $\%$} \\
\hline lysine & 0.98 & 1.11 & 1.23 & 1.35 & 1.48 \\
\hline methionine & 0.33 & 0.40 & 0.49 & 0.53 & 0.64 \\
\hline methionine+cystine & 0.59 & 0.66 & 0.74 & 0.81 & 0.88 \\
\hline threonine & 0.62 & 0.70 & 0.77 & 0.85 & 0.93 \\
\hline tryptophan & 0.22 & 0.24 & 0.27 & 0.30 & 0.32 \\
\hline isoleucine & 0.65 & 0.64 & 0.65 & 0.72 & 0.78 \\
\hline valine & 0.78 & 0.76 & 0.84 & 0.92 & 1.00 \\
\hline leucine & 1.42 & 1.40 & 1.37 & 1.37 & 1.48 \\
\hline arginine & 0.98 & 0.96 & 0.93 & 0.98 & 0.83 \\
\hline histidine & 0.43 & 0.42 & 0.41 & 0.43 & 0.47 \\
\hline phenylalanine & 0.81 & 0.79 & 0.77 & 0.80 & 0.87 \\
\hline \multicolumn{6}{|l|}{ Total AAs ${ }^{3}, \%$} \\
\hline lysine & $1.11(1.11)$ & $1.23(1.19)$ & $1.35(1.37)$ & $1.47(1.46)$ & $1.59(1.59)$ \\
\hline methionine & $0.36(0.38)$ & $0.43(0.43)$ & $0.52(0.53)$ & $0.59(0.59)$ & $0.67(0.70)$ \\
\hline methionine+cystine & $0.68(0.77)$ & $0.74(0.82)$ & $0.82(0.91)$ & $0.89(0.96)$ & $0.96(1.06)$ \\
\hline threonine & $0.73(0.75)$ & $0.81(0.80)$ & $0.87(0.87)$ & $0.95(0.96)$ & $1.03(1.02)$ \\
\hline tryptophan & $0.25(0.25)$ & $0.27(0.27)$ & $0.30(0.29)$ & $0.33(0.32)$ & $0.35(0.33)$ \\
\hline isoleucine & $0.74(0.72)$ & $0.73(0.69)$ & $0.74(0.69)$ & $0.80(0.77)$ & $0.86(0.83)$ \\
\hline valine & $0.89(0.91)$ & $0.88(0.87)$ & $0.95(0.93)$ & $1.03(1.02)$ & $1.10(1.10)$ \\
\hline leucine & $1.61(1.57)$ & $1.59(1.51)$ & $1.56(1.46)$ & $1.53(1.48)$ & $1.65(1.60)$ \\
\hline arginine & $1.06(1.18)$ & $1.04(1.10)$ & $1.01(1.06)$ & $0.96(1.03)$ & $0.90(0.97)$ \\
\hline histidine & $0.48(0.51)$ & $0.48(0.47)$ & $0.47(0.46)$ & $0.48(0.46)$ & $0.52(0.49)$ \\
\hline phenylalanine & $0.91(0.98)$ & $0.89(0.96)$ & $0.87(0.91)$ & $0.89(0.94)$ & $0.96(1.01)$ \\
\hline Calcium, $\%$ & 0.70 & 0.70 & 0.70 & 0.70 & 0.70 \\
\hline Available phosphorus, \% & 0.36 & 0.36 & 0.36 & 0.37 & 0.37 \\
\hline
\end{tabular}

CP - crude protein; NE - net energy; AAs - amino acids; ${ }^{1}$ data in parentheses indicate the analysed composition; ${ }^{2}$ see Table $1 ;{ }^{3}$ values for standardized ileal concentrations of AAs were estimated using standardized ileal digestible coefficients provided by NRC (2012) for AA and feed composition data for NE were also obtained from this source

\section{Sampling and measurements}

On day 28, one pig with the average BW $(20.45 \pm 1.17 \mathrm{~kg})$ in each pen was chosen and euthanized by a lethal dose of sodium pentobarbital (200 mg/kg BW) according to Chen et al. (2013). The abdomen was immediately opened to remove the jejunum, caecum and colon. Intestinal segment of the jejunum was collected and immediately frozen at $-80{ }^{\circ} \mathrm{C}$ for quantitative Real-Time PCR analysis. Approximately $4 \mathrm{~g}$ of the digesta from the caecum and colon were kept in sterile tubes and immediately frozen at $-80{ }^{\circ} \mathrm{C}$ until analysis of microbial DNA and short-chain fatty acids (SCFA) concentrations.

\section{Chemical analysis}

Diet samples were ground through a 1-mm screen and analysed for crude protein (CP) according to standard methods (AOAC International, 1995). The AAs composition of ingredients and diets sample was measured by ion-exchange chromatography using a Hitachi L-8800 Amino Acids Analyzer (Tokyo, Japan).

\section{Detection of mRNA expression}

Total RNA was isolated from jejunum (the entire alimentary canal without digesta) using Trizol reagent (TaKaRa, Dalian, China) according to the manufacturer's protocol. The concentration and purity of the RNA were detected spectrophotometrically (Beckman Coulter DU 800 Spectrophotometer, Beckman Coulter, Inc., Brea, CA, USA). The $\mathrm{OD}_{260}: \mathrm{OD}_{280}$ ratio (where OD - optical density) ranging from 1.8 to 2.0 in all samples was considered as suitable for further analysis. The integrity of RNA was measured by agarose gel electrophoresis and the $28 \mathrm{~S}: 18 \mathrm{~S}$ ribosomal RNA band ratio was found to be $\geq 1.8$. RNA was reverse transcribed into cDNA using PrimeScript ${ }^{\mathrm{TM}}$ RT reagent kit (TaKaRa, 
Table 3. Sequences of primers for the jejunum-related genes

\begin{tabular}{|c|c|c|c|c|}
\hline $\begin{array}{l}\text { Gene Bank } \\
\text { Acc. No. }\end{array}$ & Genes & $\begin{array}{l}\text { Primer sequence }\left(5^{\prime} \rightarrow 3^{\prime}\right) \\
(F-\text { forward, } R \text { - reverse) }\end{array}$ & $\mathrm{A}_{\mathrm{T}}^{1},{ }^{\circ} \mathrm{C}$ & Product size, bp \\
\hline \multirow[t]{2}{*}{ XM_021086047.1 } & \multirow{2}{*}{$\begin{array}{l}\text { ACTB } \\
\beta \text {-actin }\end{array}$} & F: TCTGGCACCACACCTTCT & \multirow[t]{2}{*}{60} & \multirow[t]{2}{*}{114} \\
\hline & & R: TGATCTGGGTCATCTTCTCAC & & \\
\hline \multirow[t]{2}{*}{ NM_001012613.1 } & \multirow{2}{*}{$\begin{array}{l}\text { CAT1 } \\
\text { cationic amino acids transporter } 1 \text {; } \\
\text { solute carrier family } 7 \text { member } 1 \text { (SLC7A1) }\end{array}$} & F: GAGCAAGACCAAACTCTCCTTC & \multirow[t]{2}{*}{59} & \multirow[t]{2}{*}{137} \\
\hline & & R: AGCCTATCAGCATCCACACTG & & \\
\hline \multirow[t]{2}{*}{ NM_001164649.1 } & \multirow{2}{*}{$\begin{array}{l}\text { EAAC1 } \\
\text { excitatory amino acids carrier } 1 \text {, solute carrier } \\
\text { family } 1 \text { member } 1 \text { (SLC1A1) }\end{array}$} & F: CAAACTGGGCCTTTACATGG & \multirow[t]{2}{*}{60} & \multirow[t]{2}{*}{170} \\
\hline & & R: GTGTTGCTGAACTGGAGGAGAT & & \\
\hline \multirow[t]{2}{*}{ XM_003359855.4 } & \multirow{2}{*}{$\begin{array}{l}\text { BOAT1 } \\
\text { system B0 neutral amino acids transporter; } \\
\text { solute carrier family } 6 \text { member } 19 \text { (SLC6A19) }\end{array}$} & F: ACAACAACTGCGAGAAGGACTC & \multirow[t]{2}{*}{60} & \multirow[t]{2}{*}{165} \\
\hline & & R: GCAGGTCAAACCCGTTGATAAG & & \\
\hline \multirow[t]{2}{*}{ NM_214347.1 } & PEPT1 & F: GATGCTGTGGTGTATCCTCTGA & \multirow[t]{2}{*}{60} & \multirow[t]{2}{*}{155} \\
\hline & $\begin{array}{l}\text { peptide transporter T1; solute carrier family } \\
15 \text { member } 1 \text { (SLC15A1) }\end{array}$ & R: CCTTTGGGGAAGACTGGAAGA & & \\
\hline
\end{tabular}

${ }^{1} \mathrm{~A}_{\mathrm{T}}$ - annealing temperature

Dalian, China) following the manufacturer's guidelines. Expression levels of B0AT1, CAT1, EAAC1 and $P E P T 1$ in jejunum were carried out by the Opticon DNA Engine (Bio-Rad, Hercules, CA, USA) and using SYBR Green PCR reagents (TaKaRa, Dalian, China). Primers for the selected genes (Table 3) were designed by Primer 6 Software (PREMIER Biosoft Int., Palo Alto, CA, USA) and synthesized commercially by Invitrogen (Shanghai, China). The Real-Time PCR procedure included the following cycle program: an initial pre-denaturation step at $95{ }^{\circ} \mathrm{C}$ for $30 \mathrm{~s}, 40$ cycles of denaturation at $95^{\circ} \mathrm{C}$ for $10 \mathrm{~s}$, annealing at $60^{\circ} \mathrm{C}$ for $25 \mathrm{~s}$, with a final extension at $72{ }^{\circ} \mathrm{C}$ for $5 \mathrm{~min}$. A melting curve analysis was generated following each RealTime quantitative PCR assay to check and verify the specificity and purity of all PCR products. $\beta$-actin $(A C T B)$ was chosen as the reference gene transcript and used for normalization (Lai et al., 2005). The relative expression ratio of the target gene in comparison with the reference gene was calculated using the $2^{-\triangle \Delta C T}$ method (Pfaffl, 2001). A standard curve was created from serial dilutions of one of the cDNA samples and drawn by plotting the natural $\log$ of the threshold cycle $\left(\mathrm{C}_{\mathrm{T}}\right)$ against the natural $\log$ of the number of molecules. The standard curve of each gene was run in duplicate and triplicate to obtain reliable amplification efficiency. The relative expression of target genes in the $0.98 \%$ SID Lys group was set to be 1.0. Six samples were used for each treatment and each sample was measured in triplicate. The average of each triplicate value expressed as numbers of copies was used for subsequent statistical analysis.

\section{Microbial population determination}

The digesta samples from caecum and colon were quickly collected, placed into sterile tubes, and stored at $-80^{\circ} \mathrm{C}$ until analysis. Microbial DNA from caecal and colonic digesta samples were isolated using an E.Z.N.A. ${ }^{\mathrm{TM}}$ Stool DNA Kit (Omega BioTek, Doraville, CA, USA) according to the manufacturer's instructions. The fluorescent quantitative specific primers and probe of Escherichia coli, Lactobacillus, Bifidobacterium and Bacillus were designed followed their genetic sequence of the $16 \mathrm{~S}$ rRNA. Primers and probe (Table 4) for total bacteria, Bifidobacterium, E. coli, Lactobacillus and Bacillus were used according to Diao et al. (2014). All the primers and probes were commercially synthesized by Invitrogen (Shanghai, China). The populations of total bacteria, Bifidobacterium, E. coli, Lactobacillus and Bacillus were measured through quantitative Real-Time PCR conducted with the use of CFX96 Real-Time PCR System (Bio-Rad Laboratories, Inc., Hercules, CA, USA) with optical-grade 96-well plates. To determine the total bacteria, the reaction mixture $(25 \mu 1)$ was composed of $12.5 \mu \mathrm{l}$ SYBR Premix Ex Taq (Takara, Dalian, China), $1 \mu \mathrm{l}$ of forward and $1 \mu \mathrm{l}$ of reverse primers (100 nM), $9.5 \mu 1$ nuclease-free water and $1 \mu$ DNA. The PCR procedure was: an initial pre-denaturation step at $95{ }^{\circ} \mathrm{C}$ for $10 \mathrm{~s} ; 40$ cycles of denaturation at $95{ }^{\circ} \mathrm{C}$ for $5 \mathrm{~s}$, annealing at $60{ }^{\circ} \mathrm{C}$ for $25 \mathrm{~s}$ and extension at $72{ }^{\circ} \mathrm{C}$ for $60 \mathrm{~s}$. The reaction volume for detecting Lactobacillus, E. coli, Bifidobacterium and Bacillus was $20 \mu \mathrm{l}$, composed of $1 \mu \mathrm{l}$ probe enhancer solution, $0.3 \mu$ probe $(100 \mathrm{nM}), 1 \mu$ forward and $1 \mu$ reverse primers $(100 \mathrm{nM}), 8 \mu \mathrm{l}$ Real Master 
Table 4. Sequences of primers and probes for hindgut bacteria

\begin{tabular}{|c|c|c|c|}
\hline Primer & Primers and probe sequences $\left(5^{\prime} \rightarrow 3^{\prime}\right)^{1}$ & $\mathrm{~A}_{\mathrm{T}}{ }^{2},{ }^{\circ} \mathrm{C}$ & Product size, bp \\
\hline \multirow[t]{2}{*}{ Total bacteria } & F: ACTCCTACGGGAGGCAGCAG & 60.0 & 200 \\
\hline & R:ATTACCGCGGCTGCTGG & & \\
\hline \multirow[t]{3}{*}{ Escherichia coli } & F: CATGCCGCGTGTATGAAGAA & 59.5 & 96 \\
\hline & R: CGGGTAACGTCAATGAGCAAA & & \\
\hline & Probe: AGGTATTAACTTTACTCCCTTCCTC & & \\
\hline \multirow[t]{3}{*}{ Lactobacillus } & F: GAGGCAGCAGTAGGGAATCTTC & 51.0 & 126 \\
\hline & R: CAACAGTTACTCTGACACCCGTTCTTC & & \\
\hline & Probe: AAGAAGGGTTTCGGCTCGTAAAACTCTGTT & & \\
\hline \multirow[t]{3}{*}{ Bacillus } & F: GCAACGAGCGCAACCCTTGA & 59.5 & 92 \\
\hline & R: TCATCCCCACCTTCCTCCGGT & & \\
\hline & Probe: CGGTTTGTCACCGGCAGTCACCT & & \\
\hline \multirow[t]{3}{*}{ Bifidobacterium } & F: CGCGTCCGGTGTGAAAG & 59.5 & 121 \\
\hline & R: CTTCCCGATATCTACACATTCCA & & \\
\hline & Probe: ATTCCACCGTTACACCGGGAA & & \\
\hline
\end{tabular}

${ }^{1} \mathrm{~F}$ - forward primer, $\mathrm{R}$ - reverse primer; ${ }^{2} \mathrm{~A}_{\mathrm{T}}$ - annealing temperature

Mix (Tiangen, Beijing, China), $7.7 \mu 1$ nuclease-free water and $1 \mu \mathrm{l}$ DNA. The reaction process consisted of predenaturation at $95{ }^{\circ} \mathrm{C}$ for $10 \mathrm{~s}$ and $50 \mathrm{cy}$ cles of denaturation at $95{ }^{\circ} \mathrm{C}$ for $5 \mathrm{~s}$, annealing at $55-60{ }^{\circ} \mathrm{C}$ for $25 \mathrm{~s}$ and extension at $72{ }^{\circ} \mathrm{C}$ for $60 \mathrm{~s}$. The copy numbers of total bacteria, E. coli, Lactobacillus, Bifidobacterium and Bacillus were quantified with $\mathrm{C}_{\mathrm{T}}$-values and standard curves. The respective standard curves were generated by constructing standard plasmids containing the 16s rRNA genes as described by Han et al. (2012). Deoxyribonucleic acid concentrations of standard plasmids were detected using a spectrophotometer (Beckman Coulter DU 800 Spectrophotometer, Beckman Coulter, Inc., Brea, CA, USA). A series of 10-fold dilution $\left(1 \times 10^{9}\right.$ to $1 \times 10^{1}$ copies $\left./ \mu l\right)$ of plasmids DNA were used to construct their respective standard curves. Each standard curve was generated by a linear regression of the plotted points with the logarithm of template copy numbers as the abscissa and the $\mathrm{C}_{\mathrm{T}}$ values as the ordinate.

\section{Microbial metabolites measurement}

The concentration of SCFA was determined by the gas chromatography and the method described by Diao et al. (2014). The digesta samples of caecum and colon were diluted 1:1 (wt/vol) with distilled water, centrifuged at $500 \mathrm{~g}$ for $10 \mathrm{~min}$. The supernatant fraction $(2 \mathrm{ml})$ was centrifuged at $12000 \mathrm{~g}$ for $10 \mathrm{~min}$ at $4{ }^{\circ} \mathrm{C}$, then $1 \mathrm{ml}$ supernatant was transferred to a new centrifuge tube, then added $0.2 \mathrm{ml} \mathrm{25 \%}$ meta-phosphoric acid, stood for $30 \mathrm{~min}$, the supernatants were further centrifuged at $12000 \mathrm{~g}$ for $10 \mathrm{~min}, 500 \mu \mathrm{l}$ supernatant was transferred to another centrifuge tube, then $500 \mu \mathrm{l}$ methanol was added, centrifuged at $12000 \mathrm{~g}$ for 10 min again. The clean supernatant was analysed for SCFA (acetic acid, propionic acid and butyric acid) concentrations using a gas chromatographic system (CP-3800 GC, Varian, Inc., Walnut Creek, CA, USA).

\section{Statistical analysis}

All data were subjected to one-way analysis of variance (ANOVA) for a randomized block design using the GLM procedure of SAS ver. 8.0 (SAS Institute, Inc., Cary, NC, USA). Orthogonal polynomial contrast coefficients were used to determine linear and quadratic effects of increasing SID Lys level on response criteria. For all data analysis, the individual piglet was used as the experimental unit. Differences among treatments were analysed by Duncan's multiple range test. Probability values less than 0.05 were considered significant, probability values at 0.05 to 0.1 were considered as tendency. All data are presented as means and standard error of the mean (SEM).

\section{Results}

No mortality was noted in the current study. The analysed contents of $\mathrm{CP}$ and essential AAs in all diets were close to the calculated values indicating that diets were mixed properly (Table 2).

Average daily feed intake did not differ among animals (data not shown). However, the average 
daily gain (ADG) and gain-to-feed ratio (G:F) increased linearly and quadratically from days 0 to 28 as SID Lys increased. The serum urea nitrogen (SUN) concentrations were the same on day 0 , but they decreased linearly on day 14 and decreased quadratically on day 28 as SID Lys increased. The optimal SID Lys requirement for pigs weighting 8 to $20 \mathrm{~kg}$ fed $18.5 \% \mathrm{CP}$ diet based on the average value of ADG, G:F and SUN was estimated at $1.31 \%$.

\section{The mRNA levels of nutrient transporters in jejunum}

There were no differences $(P>0.05)$ in B0AT1, EAAC1 and PEPT1 mRNA levels among the five groups (Table 5). However, the mRNA levels of $C A T 1$ in pigs fed the $1.35 \%$ SID Lys diet was higher $(P<0.01)$ in comparison to those fed the $0.98,1.11$ and $1.23 \%$ SID Lys diets, and it was similar to the $1.48 \%$ SID Lys group. Additionally, the CAT1 (linear, $P<0.01$ ), EAAC1 (linear, $P<0.05$ ) and PEPT1 (linear, $P<0.01$ ) mRNA levels increased as SID Lys levels increased in weaned pigs diet.

\section{Microbial populations in caecum and colon}

There were significant differences $(P<0.01)$ among treatment groups for the E. coli, Lactobacillus, Bacillus, Bifidobacterium and total bacteria populations in caecal digesta, whereas these bacteria among the treatment groups in colonic digesta were not influenced $(P>0.05)$ (Table 6). The populations of Lactobacillus, Bacillus, Bifidobacterium as well as the total bacteria in caecal digesta increased (linear, $P<0.01$ ) with increasing dietary SID Lys levels, at the same time, increasing SID Lys levels increased (linear, $P<0.01$ ) the population of $E$. coli in caecal digesta. Furthermore, the populations of Lactobacillus (linear, $P<0.05$ ) and Bifidobacterium (quadratic, $P<0.05$ ) increased with increasing SID Lys levels in colonic digesta.

\section{Microbial metabolites in caecum}

In the caecal digesta, the content of butyric acid was influenced $(P<0.05)$ by the different dietary SID Lys levels, whereas the acetic acid, propionic acid and total SCFA content was not influenced $(P>0.05)$ (Table 7). Moreover, the content of butyric acid was

Table 5. Effect of increasing dietary level of standardized ileal digestible lysine (SID Lys) on amino acids transporter genes expression in the jejunum of weaned pigs

\begin{tabular}{|c|c|c|c|c|c|c|c|c|c|}
\hline \multirow{2}{*}{ Gene } & \multicolumn{5}{|c|}{ SID Lys ${ }^{1}, \%$} & \multirow{2}{*}{ SEM $^{2}$} & \multicolumn{3}{|l|}{$P$-value } \\
\hline & 0.98 & 1.11 & 1.23 & 1.35 & 1.48 & & ANOVA & linear $^{3}$ & quadratic $^{3}$ \\
\hline CAT1 & $1.00^{b}$ & $1.16^{b}$ & $1.24^{b}$ & $2.02^{a}$ & $2.04^{a}$ & 0.10 & $<0.01$ & $<0.01$ & 0.48 \\
\hline BOAT1 & 1.00 & 0.91 & 0.90 & 1.12 & 0.83 & 0.15 & 0.73 & 0.76 & 0.84 \\
\hline EAAC1 & 1.00 & 1.48 & 1.32 & 1.45 & 1.36 & 0.28 & 0.23 & 0.05 & 0.08 \\
\hline PEPT1 & 1.00 & 0.89 & 1.09 & 1.15 & 1.37 & 0.19 & 0.18 & 0.01 & 0.90 \\
\hline
\end{tabular}

${ }^{1}$ see Table $1 ;{ }^{2}$ SEM - standard error of mean; ${ }^{3}$ linear and quadratic contrast for effect of SID Lys level; ab - means with different superscripts within a row are significantly different at $P<0.05$

Table 6. Effect of increasing dietary level of standardized ileal digestible lysine (SID Lys) on hindgut bacteria in the caecal and colonic digesta of weaned pigs, lg(copies/g)

\begin{tabular}{|c|c|c|c|c|c|c|c|c|c|}
\hline \multirow{2}{*}{ Indices } & \multicolumn{5}{|c|}{ SID Lys ${ }^{1}, \%$} & \multirow{2}{*}{$\mathrm{SEM}^{2}$} & \multicolumn{3}{|l|}{$P$-value } \\
\hline & 0.98 & 1.11 & 1.23 & 1.35 & 1.48 & & ANOVA & linear $^{3}$ & quadratic $^{3}$ \\
\hline \multicolumn{10}{|l|}{ Caecum } \\
\hline Escherichia coli & $8.02^{b}$ & $8.03^{b}$ & $8.41^{b}$ & $8.49^{a b}$ & $9.28^{a}$ & 0.27 & $<0.01$ & $<0.01$ & 0.32 \\
\hline Bacillus & $9.59^{b}$ & $9.73^{b}$ & $10.13^{a}$ & $10.09^{a}$ & $10.06^{a}$ & 0.05 & $<0.01$ & $<0.01$ & $<0.01$ \\
\hline Lactobacillus & $8.08^{c}$ & $8.40^{\mathrm{bc}}$ & $8.89^{\mathrm{ab}}$ & $8.84^{\mathrm{ab}}$ & $8.98^{\mathrm{a}}$ & 0.14 & $<0.01$ & $<0.01$ & 0.05 \\
\hline Bifidobacterium & $9.34^{b}$ & $9.71^{\mathrm{ab}}$ & $10.21^{a}$ & $10.19^{a}$ & $10.10^{a b}$ & 0.18 & 0.01 & 0.01 & 0.07 \\
\hline Total bacteria & $11.08^{b}$ & $11.13^{b}$ & $11.41^{\mathrm{a}}$ & $11.37^{\mathrm{a}}$ & $11.44^{\mathrm{a}}$ & 0.06 & $<0.01$ & $<0.01$ & 0.14 \\
\hline \multicolumn{10}{|l|}{ Colon } \\
\hline Escherichia coli & 7.86 & 7.94 & 7.78 & 8.05 & 8.48 & 0.29 & 0.34 & 0.15 & 0.48 \\
\hline Bacillus & 9.97 & 9.97 & 9.96 & 9.83 & 9.82 & 0.06 & 0.15 & 0.06 & 0.64 \\
\hline Lactobacillus & 8.91 & 8.87 & 9.12 & 9.09 & 9.19 & 0.12 & 0.34 & 0.04 & 0.88 \\
\hline Bifidobacterium & 9.94 & 10.25 & 10.32 & 10.18 & 10.14 & 0.14 & 0.07 & 0.13 & 0.02 \\
\hline Total bacteria & 11.44 & 11.58 & 11.50 & 11.36 & 11.47 & 0.06 & 0.19 & 0.41 & 0.65 \\
\hline
\end{tabular}

${ }^{1}$ see Table $1 ;{ }^{2}$ SEM - standard error of mean; ${ }^{3}$ linear and quadratic contrast for effect of SID Lys level; abc - means with different superscripts within a row are significantly different at $P<0.05$ 
Table 7. Effect of increasing dietary level of standardized ileal digestible lysine (SID Lys) on the short-chain fatty acids (SCFA) concentrations in caecal digesta of weaned pigs

\begin{tabular}{|c|c|c|c|c|c|c|c|c|c|}
\hline \multirow{2}{*}{ Indices } & \multicolumn{5}{|c|}{ SID Lys ${ }^{1}, \%$} & \multirow{2}{*}{ SEM $^{2}$} & \multicolumn{3}{|l|}{$P$-value } \\
\hline & 0.98 & 1.11 & 1.23 & 1.35 & 1.48 & & ANOVA & linear $^{3}$ & quadratic $^{3}$ \\
\hline Acetic acid, mg/g & 4.20 & 3.78 & 3.81 & 3.49 & 3.51 & 0.30 & 0.52 & 0.09 & 0.58 \\
\hline Propionic acid, mg/g & 2.25 & 2.40 & 2.19 & 2.26 & 1.84 & 0.15 & 0.18 & 0.09 & 0.23 \\
\hline Butyric acid, mg/g & $0.70^{\mathrm{b}}$ & $0.90^{\mathrm{ab}}$ & $0.91^{\mathrm{ab}}$ & $1.18^{\mathrm{a}}$ & $0.80^{\mathrm{ab}}$ & 0.09 & 0.02 & 0.20 & 0.04 \\
\hline Total SCFA, mg/g & 7.16 & 7.08 & 6.91 & 6.94 & 6.15 & 0.43 & 0.57 & 0.16 & 0.55 \\
\hline
\end{tabular}

${ }^{1}$ see Table $1 ;{ }^{2}$ SEM - standard error of mean; ${ }^{3}$ linear and quadratic contrast for effect of SID Lys level; ab - means with different superscripts within a row are significantly different at $P<0.05$

increased (quadratic, $P<0.05$ ) with increasing dietary SID Lys levels and the $1.35 \%$ SID Lys treatment showed a significantly higher content of butyric acid than the other treatments $(P<0.05)$.

\section{Discussion}

Animal life is built of many gene expression processes. These processes are genetically preprogrammed, but dietary nutrients play a crucial role in activating these processes (Liao et al., 2015). It has been reported that regulation of nutrient transporters in the small intestine is connected with the nutrients present in the diet (Gilbert et al., 2008). Amino acids are transported by neutral, acidic or basic AAs transporters $(\mathrm{Wu}$, 2013). B0AT1 is the major apical neutral amino acid transporter in the kidney and the small intestine (Bröer, 2008). CAT plays an important role in the transport and maintenance of homeostasis of basic AAs (arginine, histidine, lysine and ornithine) in the small intestine (Bröer et al., 2000; Hyde et al., 2003). Peptide transport which is $\mathrm{H}^{+}$-dependent is one of the major routes of AAassimilation by the enterocyte (Chen et al., 2002). In the present study, the mRNA levels of B0AT1,EAAC1 and PEPT1 in jejunum were not influenced by dietary SID Lys levels. However, different dietary SID Lys levels affected the mRNA level of CAT1 in jejunum, which is in line with the recent reports stating that diets with different Lys levels have different effects on the expression of cationic AAs transporters in the small intestine of weaned pigs (GarcíaVillalobos et al., 2012; Wang et al., 2012). Moreover, the quantities of CAT1 mRNA in the $1.35 \%$ SID Lys group were greater in jejunum, and the mRNA levels of CATl linearly increased as dietary SID Lys increased significantly. Likewise, increasing mRNA levels of EAAC1 and PEPT1 were connected by increasing SID Lys. Thus, it may imply that diets with higher SID Lys content (i.e. 1.35\%
SID Lys) may improve the transport capacity of some AAs in the small intestine.

In the gastrointestinal tract the populations and species of microbes affect the nutrient digestibility and have an impact on gut health (Yang et al., 2010). It is widely known that Lactobacilli, Bacillus and Bifidobacterium are considered as beneficial gut bacteria, whereas E. coli are often harmful. Microbial population in the gastrointestinal tract is dependent on the diet composition (Yin et al., 2009; Blachier et al., 2010). It seems that the available amounts of substrates for bacterial proliferation in the gastrointestinal tract may be affected by reducing dietary protein levels and supplementating AAs to low protein diets (Dai et al., 2011). The results of the present study indicate that the populations of E. coli, Lactobacilli, Bacillus and Bifidobacterium total bacteria in the caecal digesta were influenced by dietary levels of SID Lys, and all of them increased linearly as dietary SID Lys increased. Furthermore, the results of Lactobacilli, Bacillus and Bifidobacterium populations may suggest that increasing dietary SID Lys levels decreased the amounts of substrates for bacterial proliferation which was beneficial for hindgut health. In the present study, the crystalline AA was increased as dietary SID Lys level increased and it is well known that free AA are completely absorbed to the end of the small intestine. It can be expected that protein content or other AA content in pig digesta reaching the large intestine was decreased with increasing SID Lys level. Indeed, in another study at our laboratory, it was found that the apparent total tract digestibilities of crude protein and all essential AAs in $1.35 \%$ SID Lys group were higher than in $1.23 \%$ SID Lys group (data unpublished). Moreover, it was noted that the higher levels of by L-Lys and maize with reduced soybean meal, the increased concentration of starch (and fibre) in the highest Lys diet. Protein fermentation can contribute to yield toxic metabolites (e.g., sulphur-containing compounds, ammonia and several phenolic and 
indolic compounds) (Egert et al., 2006) whereas carbohydrate fermentation leads to the appearance of perceived health-promoting metabolites such as short-chain fatty acids and reduction of ammonia and amines in the pig hindgut (Scheppach, 1994; Pieper et al., 2012). These facts may be the main reason for the observed results. However, the results concerning E. coli were in the contrary. In the diets with high SID Lys level the imbalance of Lys can result in not successful utilisation of all protein (AA), leading to the degradation of protein/AA which can enter the hindgut and also produce the urea. We have also found increased plasma urea $\mathrm{N}$ in animals fed Lys or other AA imbalanced diets (data not shown) suggesting increased population of $E$. coli in the $1.48 \%$ SID Lys group.

Furthermore, in the current study it was found that populations of Lactobacillus and Bifidobacterium in the colonic digesta increased linearly and quadratically as SID Lys increased. Taking into account the results mentioned above, it is suggested that appropriately increased dietary SID Lys levels may have positive influence of the number of beneficial bacteria in the hindgut of weaned pigs. Moreover, further research is needed to reveal the effects of dietary SID Lys levels on the microbial population of weaned pigs.

Short-chain fatty acids (SCFA) are the major end products of the fermentation processes of intestinal microflora in the large intestine (Bergen and $\mathrm{Wu}, 2009$ ), and are diet type- and microbial composition-dependent (van Beers-Schreurs et al., 1998). SCFA, particularly butyrate, are the major and preferred metabolic substrates for colonocytes providing at least $60-70 \%$ of their energy requirements necessary for their proliferation and differentiation (Suzuki et al., 2008). They can also maintain normal morphology of intestinal mucosal epithelial cells as well as the normal function of the intestinal mucosa barrier as well as inhibit intestinal inflammatory reaction (Ferreira et al., 2012). In the present study, the concentration of butyric acid increased quadratically with increasing SID Lys and maximize in $1.35 \%$ SID Lys group. Moreover, it was previously reported that a higher concentration of acetic and propionic acids can inhibit the activity of bacteria which produce butyric acid (Duncan et al., 2007). Interestingly, in current study the concentrations of acetic and propionic acids tended to decrease linearly. Thus, diet with $1.35 \%$ SID Lys may be beneficial for promoting the production of butyrate in the hindgut of weaned pigs.

\section{Conclusions}

The cationic amino acids transporter 1 (CAT1) mRNA expression, the populations of bacteria and the content of butyric acid in weaned pigs were significantly influenced by different dietary standardized ileal digestible lysine (SID Lys) levels. When dietary SID Lys level was $1.35 \%$ it contributed, to some extent, to increasing absorption of amino acids and promoted the hindgut health of weaned pigs.

\section{Acknowledgements}

This study was supported by Sichuan Province Key Technology Research and Development Program (Grant No. 2015NZ0042, 2016NZ0006) and Evonik Nutrition \& Care GmbH (Germany).

\section{References}

AOAC International, 1995. Official Methods of Analysis of AOAC International. $16^{\text {th }}$ Edition. Arlington, VA (USA)

Apple J.K., Maxwell C.V., Brown D.C., Friesen K.G., Musser R.E., Johnson Z.B., Armstrong T.A., 2004. Effects of dietary lysine and energy density on performance and carcass characteristics of finishing pigs fed ractopamine. J. Anim. Sci. 82, 3277-3287, https://doi.org/10.2527/2004.82113277x

Bergen W.G., Wu G.Y., 2009. Intestinal nitrogen recycling and utilization in health and disease. J. Nutr. 139, 821-825, https://doi. org/10.3945/jn.109.104497

Blachier F., Lancha A.H. Jr., Boutry C., Tomé D., 2010. Alimentary proteins, amino acids and cholesterolemia. Amino Acids 38, 15-22, https://doi.org/10.1007/s00726-009-0239-6

Bröer A., Wanger C.A., Lang F., Bröer S., 2000. The heterodimeric amino acid transporter 4F2hc/y+LAT2 mediates arginine efflux in exchange with glutamine. Biochem. J. 349, 787-795, https:// doi.org/10.1042/bj3490787

Bröer S., 2008. Amino acid transport across mammalian intestinal and renal epithelia. Physiol. Rev. 88, 249-286, https://doi. org/10.1152/physrev.00018.2006

Cameron N.D., McCullough E., Troup K., Penman J.C., 2003. Serum urea concentration as a predictor of dietary lysine requirement in selected lines of pigs. J. Anim. Sci. 81, 91-100, https://doi. org/10.2527/2003.81191x

Chen H., Mao X.B., He J., Yu B., Huang Z., Yu J., Zheng P., Chen D., 2013. Dietary fibre affects intestinal mucosal barrier function and regulates intestinal bacteria in weaning piglets. $\mathrm{Br}$. J. Nutr. 110, 1837-1848, https://doi.org/10.1017/S0007114513001293

Chen H., Pan Y., Wong E.A., Bloomquist J.R., Webb K.E. Jr, 2002. Molecular cloning and functional expression of a chicken intestinal peptide transporter (cPepT1) in Xenopus oocytes and Chinese hamster ovary cells. J. Nutr. 132, 387-393, https://doi. org/10.1093/jn/132.3.387

Dai Z.-L., Wu G., Zhu W.Y., 2011. Amino acid metabolism in intestinal bacteria: links between gut ecology and host health. Front. Biosci. 16, 1768-1786, https://doi.org/10.2741/3820

Diao H., Zheng P., Yu B., He J., Mao X.B., Yu J., Chen D.W., 2014. Effects of dietary supplementation with benzoic acid on intestinal morphological structure and microflora in weaned piglets. Livest. Sci. 167, 249-256, https://doi.org/10.1016/j. livsci.2014.05.029 
Duncan S.H., Belenguer A., Holtrop G., Johnstone A.M., Flint H.J., Lobley G.E., 2007. Reduced dietary intake of carbohydrates by obese subjects results in decreased concentrations of butyrate and butyrate-producing bacteria in feces. Appl. Environ. Microbiol. 73, 1073-1078, https://doi.org/10.1128/ AEM.02340-06

Egert M., de Graaf A.A., Smidt H., de Vos W.M., Venema K., 2006. Beyond diversity: functional microbiomics of the human coIon. Trends Microbiol. 14, 86-91. https://doi.org/10.1016/j. tim.2005.12.007

Ferreira T.M., Leonel A.J., Melo M.A., Santos R.R.G., Cara D.C., Cardoso V.N., Correia M.I.T.D., Alvarez-Leite J.I., 2012. Oral supplementation of butyrate reduces mucositis and intestinal permeability associated with 5 -fluorouracil administration. Lipids 47, 669-678, https://doi.org/10.1007/s11745-012-3680-3

García-Villalobos H., Morales-Trejo A., Araiza-Piña B.A., Htoo J.K., Cervantes-Ramírez M., 2012. Effects of dietary protein and amino acid levels on the expression of selected cationic amino acid transporters and serum amino acid concentration in growing pigs. Arch. Anim. Nutr. 66, 257-270, https://doi.org /10.1080/1745039X.2012.697351

Gatrell S.K., Berg L.E., Barnard J.T., Grimmett J.G., Barnes K.M., Blemings K.P., 2013. Tissue distribution of indices of lysine catabolism in growing swine. J. Anim. Sci. 91, 238-247, https://doi.org/10.2527/jas.2011-5070

Gilbert E.R., Li H., Emmerson D.A., Webb K.E. Jr, Wong E.A., 2008. Dietary protein quality and feed restriction influence abundance of nutrient transporter mRNA in the small intestine of broiler chicks. J. Nutr. 138, 262-271, https://doi.org/10.1093/ jn/138.2.262

Han G.-Q., Xiang Z.-T., Yu B., Chen D.-W., Qi H.-W., Mao X.-B., Chen H., Mao Q., Huang Z.-Q., 2012. Effects of different starch sources on Bacillus spp. in intestinal tract and expression of intestinal development related genes of weanling piglets. Mol. Biol. Rep. 39, 1869-1876, https://doi.org/10.1007/ s11033-011-0932-x

Hu Y., Smith D.E., Ma K., Jappar D., Thomas W., Hillgren K.M., 2008. Targeted disruption of peptide transporter Pept1 gene in mice significantly reduces dipeptide absorption in intestine. Mol. Pharm. 5, 1122-1130, https://doi.org/10.1021/mp8001655

Hyde R., Taylor P.M., Hundal H.S., 2003. Amino acid transporters: roles in amino acid sensing and signalling in animal cells. Biochem. J. 373, 1-18, https://doi.org/10.1042/bj20030405

Jobgen W.S., Fried S.K., Fu W.J., Meininger C.J., Wu G., 2006. Regulatory role for the arginine-nitric oxide pathway in metabolism of energy substrates. J. Nutr. Biochem. 17, 571-588, http:// doi.org/10.1016/j.jnutbio.2005.12.001

Kanai Y., Hediger M.A., 2003. The glutamate and neutral amino acid transporter family: physiological and pharmacological implications. Eur. J. Pharmacol. 479, 237-247, https://doi. org/10.1016/j.ejphar.2003.08.073

Kim Y.W., Ingale S.L., Kim J.S., Kim K.H., Chae B.J., 2011. Effects of dietary lysine and energy levels on growth performance and apparent total tract digestibility of nutrients in weanling pigs. Asian-Australas. J. Anim. Sci. 24, 1256-1267, https://doi. org/10.5713/ajas.2011.11134

Lai C., Yin J., Li D., Zhao L., Qiao S., Xing J., 2005. Conjugated linoleic acid attenuates the production and gene expression of proinflammatory cytokines in weaned pigs challenged with lipopolysaccharide. J Nutr. 135, 239-244, https://doi.org/10.1093/ jn/135.2.239

Laspiur J.P., Burton J.L., Weber P.S.D., Moore J., Kirkwood R.N., Trottier N.L., 2009. Dietary protein intake and stage of lactation differentially modulate amino acid transporter mRNA abundance in porcine mammary tissue. J. Nutr. 139, 1677-1684, https://doi.org/10.3945/jn.108.103549
Leibach F.H., Ganapathy V., 1996. Peptide transporters in the intestine and the kidney. Annu. Rev. Nutr. 16, 99-119, https://doi. org/10.1146/annurev.nu.16.070196.000531

Liao S.F., Wang T., Regmi N., 2015. Lysine nutrition in swine and the related monogastric animals: muscle protein biosynthesis and beyond. Springerplus. 4, 147, https://doi.org/10.1186/s40064015-0927-5

NRC (National Research Council), 2012. Nutrient Requirements of Swine. $11^{\text {th }}$ Revised Edition. The National Academies Press. Washington, DC (USA), https://doi.org/10.17226/13298

Pfaffl M.W., 2001. A new mathematical model for relative quantification in real-time RT-PCR. Nucleic Acids Res. 29, e45, https://doi. org/10.1093/nar/29.9.e45

Pieper R., Kröger S., Richter J.F. et al., 2012. Fermentable fiber ameliorates fermentable protein-induced changes in microbial ecology, but not the mucosal response, in the colon of piglets. J. Nutr, 142, 661-667, https://doi.org/10.3945/jn.111.156190

Qin J., Li R., Raes J. et al., 2010. A human gut microbial gene catalogue established by metagenomic sequencing. Nature 464 , 59-65, https://doi.org/10.1038/nature08821

Regnault T.R., de Vrijer B., Battaglia F.C., 2002. Transport and metabolism of amino acids in placenta. Endocrine 19, 23-41, https:// doi.org/10.1385/ENDO:19:1:23

Ren J.-B., Zhao G.-Y., Li Y.-X., Meng Q.-X., 2007. Influence of dietary lysine level on whole-body protein turnover, plasma IGF-I, GH and insulin concentration in growing pigs. Livest. Sci. 110, 126-132, http://doi.org/10.1016/j.livsci.2006.10.009

Scheppach W., 1994. Effects of short chain fatty acids on gut morphology and function. Gut 35, Suppl. 1, S35-38, https://doi. org/10.1136/gut.35.1_Suppl.S35

Suenaga R., Tomonaga S., Yamane H., Kurauchi I., Tsuneyoshi Y., Sato H., Denbow D.M., Furuse M., 2008. Intracerebroventricular injection of $\mathrm{L}$-arginine induces sedative and hypnotic effects under an acute stress in neonatal chicks. Amino Acids 35, 139-146, https://doi.org/10.1007/s00726-007-0610-4

Suzuki T., Yoshida S., Hara H., 2008. Physiological concentrations of short-chain fatty acids immediately suppress colonic epithelial permeability. Br. J. Nutr. 100, 297-305, https://doi. org/10.1017/S0007114508888733

van Beers-Schreurs H.M., Nabuurs M.J.A., Vellenga L., Kalsbeek-van der Valk H.J., Wensing T., Breukink H.J., 1998. Weaning and the weanling diet influence the villous height and crypt depth in the small intestine of pigs and alter the concentrations of short-chain fatty acids in the large intestine and blood. J. Nutr. 128, 947-953, https://doi.org/10.1093/jn/128.6.947

Verrey F., Closs E.I., Wagner C.A., Palacin M., Endou H., Kanai Y., 2004. CATs and HATs: the SLC7 family of amino acid transporters. Pflügers Arch. 447, 532-542, https://doi.org/10.1007/ s00424-003-1086-z

Wang X.-Q., Zeng P.-L., Feng Y., .Zhang C.-M., Yang J.-P., Shu G., Jiang Q.-Y., 2012. Effects of dietary lysine levels on apparent nutrient digestibility and cationic amino acid transporter mRNA abundance in the small intestine of finishing pigs, Sus scrofa. Anim. Sci. J. 83, 148-155, https://doi.org/10.1111/ j.1740-0929.2011.00941.x

Wu G., 2013. Amino Acids: Biochemistry and Nutrition. CRC Press. Boca Raton, FL (USA)

Yang Y., Kiarie E., Slominski B.A., Brûlé-Babel A., Nyachoti C.M., 2010. Amino acid and fiber digestibility, intestinal bacterial profile, and enzyme activity in growing pigs fed dried distillers grains with solubles-based diets. J. Anim. Sci. 88, 3304-3312, https://doi.org/10.2527/jas.2009-2318 
Yin F.G., Liu Y.L., Yin Y.L., Kong X.F., Huang R.L., Li T.J., Wu G.Y., Hou Y., 2009. Dietary supplementation with Astragalus polysaccharide enhances ileal digestibilities and serum concentrations of amino acids in early weaned piglets. Amino Acids 37, 263-270, https://doi.org/10.1007/s00726-0080142-6
Zhang C., Zhang M., Wang S. et al., 2010. Interactions between gut microbiota, host genetics and diet relevant to development of metabolic syndromes in mice. ISME. J. 4, 232-241, https:// doi.org/10.1038/ismej.2009.112 